\title{
Availability of information on young onset dementia for patients and carers in six European countries
}

\author{
Bridget Jones $^{\mathrm{a}, *}$, Heather Gage ${ }^{\mathrm{a}}$, Christian Bakker ${ }^{\mathrm{b}}$, Helena Barrios $^{\mathrm{c}}$, Sarah Boucault ${ }^{\mathrm{d}}$, \\ Johannes Mayer ${ }^{\mathrm{e}}$, Anna Metcalfe ${ }^{\mathrm{d}}$, Joany Millenaar ${ }^{\mathrm{b}}$, Wendy Parker ${ }^{\mathrm{a}}$, \\ Anneli Orrung Wallin ${ }^{\mathrm{f}}$, on behalf of the RHAPSODY Study Group ${ }^{1}$ \\ a Surrey Health Economics Centre, School of Economics, University of Surrey, Guildford, Surrey, GU2 7XH England, UK \\ ${ }^{\mathrm{b}}$ School for Mental Health and Neuroscience, Alzheimer Center Limburg, Maastricht University Medical Center, Maastricht, The Netherlands \\ ${ }^{\mathrm{c}}$ Institute of Molecular Medicine and Faculty of Medicine, University of Lisbon, Portugal \\ d Université Pierre et Marie Curie, Hôpital Pitié Salpêtrière, Paris, France \\ e Department of Psychiatry and Psychotherapy, Klinikum rechts der Isar, Technische Universität München, Munich, Germany \\ ${ }^{\mathrm{f}}$ Department of Health and Society, Kristianstad University, Kristianstad, Sweden
}

\section{A R T I C L E I N F O}

\section{Article history:}

Received 24 January 2017

Received in revised form 4 April 2017

Accepted 10 July 2017

\section{Keywords:}

Young onset dementia

Information

European countries

\begin{abstract}
A B S T R A C T
Objectives: To identify information available in six European countries (England, France, Germany, Netherlands, Portugal, Sweden) that addresses the specific needs of people with young onset dementia (YOD) and their carers, and identify gaps.

Methods: Search of websites of organisations with potential interest in dementia. Narrative synthesis and comparative analysis.

Results: 21 sources of information were identified (Netherlands 6, England 6, France 3, Germany 2, Portugal 2, Sweden 2); 11 were from voluntary sector organisations. Sources dedicated to YOD were limited ( 4 websites, 4 books); all other YOD information was sub-entries in generic dementia sources, difficult to locate and with limited coverage of relevant topics. Gaps related to implications of living with YOD in Germany, Portugal and Sweden.

Conclusion: Availability of information varies among countries, some having no dedicated source and incomplete coverage of issues of importance to YOD.

Practical implications: Information is an important means of supporting carers; their needs change as the condition progresses. A comprehensive resource collating key information is needed so that the issues that differentiate the specific needs of people living with YOD from those of people with dementia in older age are available and easily located.
\end{abstract}

(C) 2017 Published by Elsevier Ireland Ltd.

\section{Introduction}

Dementia is usually associated with ageing and its rising prevalence is explained by increasing longevity [1,2]. Many countries have responded to this major public health concern by implementing strategies on prevention, treatment and support [3]. Young onset dementia (YOD), defined as first symptoms before 65 years of age, is comparatively uncommon, with an estimated prevalence, between
45 and 64 years, of 100 individuals per 100,000 population in Europe, Japan and the United States [4], and an annual incidence of 5 to 20 cases per 100,000 person years [5]. With most European health and social care focused on older-age dementia, a lack of age-appropriate services for YOD has been identified, and there is concern that the needs of YOD are unmet [6,7].

YOD differs from later-onset dementia in a number of aspects, including greater heritability [8]. Atypical Alzheimer's disease is

\footnotetext{
* Corresponding author.

E-mail addresses: b.e.jones@surrey.ac.uk (B. Jones), h.gage@surrey.ac.uk (H. Gage), Christian.Bakker@radboudumc.nl (C. Bakker), helenabarrios@gmail.com (H. Barrios),

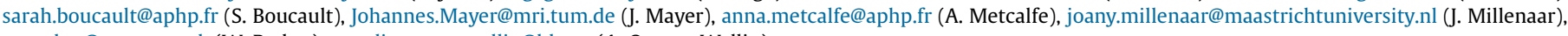
w.parker@surrey.ac.uk (W. Parker), anneli.orrung_wallin@hkr.se (A. Orrung Wallin).

${ }^{1}$ The RHAPSODY Study Group also includes the following: England: Jan Oyebode; France: Bruno Dubois, Thierry Hergueta; Germany: Markus Böhm, Alexander Komar,

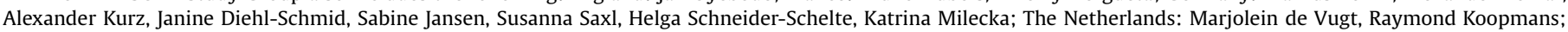

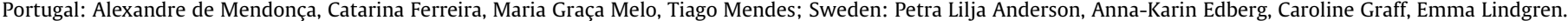


more common in YOD, presenting through non-memory problems, such as language or visuo-spatial dysfunctions, and impaired executive functioning, organizational and planning skills $[9,10]$. Similarly, greater frequency of frontotemporal degenerations in YOD produces behavioural changes, for example inappropriate social interactions, lack of empathy, poor motivation and general apathy [11,12]. With such early symptoms developing gradually, diagnosis is often difficult and delayed. Moreover, the pathophysiological differences between YOD and dementia in older age give rise to different disease trajectories [12] that require specialised treatment and management [13].

YOD presents particular problems with broad social, psychological and familial implications. The growing awareness of genetic factors underlying YOD results in uncertainty about the future among relatives and concern for the next generation. The person diagnosed is forced to retire, while relatives also have to cut working hours to adopt caring roles, thus reducing family income. Children's situations are disrupted, with some also taking on caring responsibilities [14]. Managing behavioural symptoms in the physically active is challenging, particularly for relatively young carers, who are unprepared for such a role and are facing difficulties accepting and understanding the condition [15,16]. Such changing family dynamics create conflicting priorities that add to the day-to-day stress and problems of coping with the situation [17-19].

We aimed to identify the availability of information that specifically addressed the particular needs of families living with YOD in six European countries (England, France, Germany, Netherlands, Portugal, Sweden), and highlight gaps. This work formed part of a project that aimed to assess policies and strategies for dementia in the young (Rhapsody), and to develop information resources for carers.

\section{Materials and methods}

Searches for YOD information for patients and carers were conducted between September and December 2014. Standardised research procedures were maintained via in-person and Skype meetings, teleconferences and email. Ethical approval was not required as no participants were recruited.

Websites of organisations with potential interest in dementia were targeted: national and regional government agencies; professional and provider associations; third sector (voluntary, charity) patient advocacy groups; and pharmaceutical companies. Lists of organisations were developed in all countries with local YOD experts. Lateral searching covered other potential sources.

Entire websites of YOD agencies were included. The YODspecific content within websites of organisations with broader remits was identified using search terms (dementia, young/er onset, early onset, pre-senile, younger people, working age, carer) applied in local languages. YOD information was saved for analysis and links to YOD resources were followed. All accessible styles and media forms were relevant, including online text, printed copies (fact sheets, booklets, articles, books) and audio or audio-visual items (recordings, films, DVDs). Eligibility was based on source and content: sources had to be recognised organisations or authorities (government, public agencies, professional or provider organisations, industry, advocacy groups), and content had to be nationally relevant. Independent personal accounts, opinions, output from local meetings and blogs were excluded as content may not have been checked for accuracy.

Details were recorded in an Excel spreadsheet: title, author/ agency/publisher, date, format of material, approximate size (pages/length), website address, date accessed. A brief description of YOD content was provided. Each country prepared a report (in
English) that included the spreadsheet, an overview of material available and signposted information gaps.

Country reports were subject to narrative synthesis and comparative analysis in England, involving individual discussions with countries to clarify understanding and ensure consistency in the items that were included. This process resulted in some materials being dropped. The content descriptions of the retained items were reviewed and evaluated by two independent researchers in order to identify topics covered. These were discussed and refined to define eight key subject areas: general YOD background; types and symptoms; diagnosis; treatment and therapies; social and emotional (family perspectives, loss, bereavement); formal implications (employment, driving, legal, financial); residential (technology, home adaptations for independence, respite and long-term care); resources (help and support). This provided a picture of the overall availability of information by country and gaps in coverage. The overview was used to help develop a new online resource for carers. The subtopics included in each of the topic areas are listed in Table 1. Results were verified in each country at each stage of the synthesis.

The continued availability of sources was checked in October 2016 and the search was updated to identify new resources.

\section{Results}

\subsection{Agencies}

Initial searches identified 21 sources: six each in the Netherlands and England, three in France, and two each in Germany, Portugal and Sweden. Two years later, the same sources were still available, although some web addresses had changed and some content had been extended. No new eligible sources were identified. About half $(11 / 21)$ the sources were from the third/ voluntary sector. No professional associations or pharmaceutical companies provided information. In the Netherlands, information was produced by a group of nursing homes and a tertiary (clinical) Alzheimer's Centre collaborating with a University (Table 2).

\section{Sources}

Four dedicated YOD websites were identified, three voluntary sector (Young Dementia UK in England, national Young Dementia Reference Centre in France, and Alzheimer's Society in Portugal) and the tertiary Alzheimer's Centre/University collaboration in the Netherlands. Four books (two each in England and Netherlands) written for people with YOD and carers were identified from 'other resources' sections of websites. All other YOD information was provided as sub-entries within generic dementia sources, including Alzheimer's Societies in all countries except Sweden, the National Health Service and Social Care Institute of Excellence in England, public broadcasting channels in the Netherlands, two national government agencies in Sweden, a non-profit organisation producing training materials in Portugal, and a commercial health information service in France. Some sources provided multiple items on YOD. Videos were available in England (2), France (2) and the Netherlands (4). Appendix A lists sources and items.

\subsubsection{Content of materials}

Comprehensive information was provided by single sources in the Netherlands, England and France (three websites and three books). Topic coverage by other sources was piecemeal, but most 
Table 1

Details of content identified and categorised in subject areas covered by information sources.

\begin{tabular}{|c|c|}
\hline Final Subject Areas & Content Coverage and Codes \\
\hline YOD Background & $\begin{array}{l}\text { Dementia definitions, descriptions, overview of types } \\
\text { YOD characteristics, related issues } \\
\text { Special needs arising in YOD } \\
\text { Health and social care: formal services overview }\end{array}$ \\
\hline $\begin{array}{l}\text { Medical: types, } \\
\text { symptoms }\end{array}$ & $\begin{array}{l}\text { Dementia physiology, presentation, explanation, } \\
\text { background } \\
\text { Definitions, specific explanations of YOD types } \\
\text { Symptom description, presentation, comparisons }\end{array}$ \\
\hline Medical: diagnosis & $\begin{array}{l}\text { Symptom awareness, identification issues } \\
\text { Diagnosis process, YOD recognition issues, tests }\end{array}$ \\
\hline $\begin{array}{l}\text { Medical: treatment, } \\
\text { therapy }\end{array}$ & $\begin{array}{l}\text { Drug treatments } \\
\text { Professional health therapy: speech, physiotherapy, } \\
\text { occupational } \\
\text { Complementary and alternative medicines and } \\
\text { therapies }\end{array}$ \\
\hline Social and emotional & $\begin{array}{l}\text { Emotional issues, psychological impact of YOD, } \\
\text { support } \\
\text { Concept of loss, carer/family context } \\
\text { Understanding bereavement } \\
\text { Family implications and impact, children and YOD } \\
\text { Social context, YOD rarity, stigma, individual/family } \\
\text { impact }\end{array}$ \\
\hline $\begin{array}{l}\text { Formal, financial and } \\
\text { legal }\end{array}$ & $\begin{array}{l}\text { Employment, work implications, responsibilities, } \\
\text { impact } \\
\text { Employment adjustments, voluntary occupations } \\
\text { Activity and YOD } \\
\text { Access issues, travel, mobility } \\
\text { Driving impact, concerns and implications } \\
\text { Financial information, considerations, implications } \\
\text { Legal considerations, future awareness, forward } \\
\text { planning }\end{array}$ \\
\hline Residential aspects & $\begin{array}{l}\text { Respite support, care options } \\
\text { Residential availability, access, implications, adapting } \\
\text { Care at home, minor changes, key adaptations, } \\
\text { considerations } \\
\text { Helpful technology }\end{array}$ \\
\hline $\begin{array}{l}\text { Resources, help, } \\
\text { support }\end{array}$ & $\begin{array}{l}\text { Recognising needs, acknowledging value of support } \\
\text { Identifying relevant resources } \\
\text { Locating, approaching, managing, adjusting available } \\
\text { sources }\end{array}$ \\
\hline
\end{tabular}

frequently focused on medical aspects. In Germany, Portugal and Sweden, gaps related particularly to implications of living with YOD, such as employment, finance, driving and legal issues (Table 3).

\section{Discussion and conclusions}

\subsection{Discussion}

Information for patients and carers in the six European countries was found to be variable, with the broadest range and most comprehensive coverage of topics in the Netherlands, followed by England and France. Searches suggested that access to information is less good in Germany, Portugal and Sweden. Overall, the focus was on medical aspects, rather than the implications of living with YOD, even though studies of information needs of carers of people with dementia indicate varied and changing needs, including anxiety related to disease progression, the dying process and psychosocial issues [20-23]. Guidance on financial and legal matters [21], and help with practical problems and emotional, as well as physical, coping strategies [24,20] are also paramount. Except in Sweden, the voluntary/charity sector plays a major role in provision of information, while governments and provider organisations (other than in the Netherlands) have limited involvement.

Lack of attention to YOD may reflect its low prevalence compared to other chronic illnesses and the assumption that it is covered within dementia as a whole. Information was easily accessible from organisations dedicated to YOD, but YOD facts on websites with wider remits were often integrated - and lost within detail on general dementia. Details were difficult to locate and, often, they failed to reflect relevant differences between YOD needs and those of older people. Poor internet search pathways to specific YOD information indicate the importance of developing targeted resources while little recognition of specific YOD needs highlights gaps in resources. However, dedicated websites are not necessarily comprehensive, for example, the Alzheimer's France website provided more varied information on YOD than the French national reference centre on YOD. Websites provide links to resources, which, although helpful, lengthens the search processes.

International information searches were conducted consistently and with rigour. For accuracy and quality, only items produced by recognised bodies were included. Using the internet as the primary resource, however, could have missed other items which would be important for households without internet access (some 20\% of European households in 2014 [25]). Items from regional groups were excluded unless they were produced for national dissemination. This may have affected results in Sweden where health care is organised by local municipalities. The picture of information availability reflects a snapshot at one point in time, and increasing awareness of YOD is resulting in an evolving information environment. Some websites were updated in the two years between searches but there were no significant new resources. Subsequently, however, the Alzheimer's Society in the UK has produced an eighty page booklet on understanding the YOD diagnosis [26].

\subsection{Conclusion}

Availability of information for people with YOD and carers is variable across the six European countries in this study. Some countries have no dedicated source, making it difficult to locate information. Specific issues differentiating the needs and concerns of people with YOD from those of people who develop older-age dementia are not comprehensively covered.

\subsection{Practice implications}

Families living with long-term illness seek information as a coping strategy to ease continuous lifestyle changes and related psychosocial adjustment, for example with role transition and social stigma associated with dementia $[27,23]$. In health and social care, information provision is important for enabling self care, thereby reducing demands on formal services, and support for family carers is viewed as an indispensable and effective component of dementia management, providing benefits to patients [28] and carers alike [29,30]. Hence, European guidelines highlight carer support as an integral part of treatment [31]. A comprehensive resource collating key information is likely to be the most helpful way to fill the information gap for families living with YOD. The RHAPSODY project is developing an online program to support carers of people with YOD [32] and working with patient advocacy groups to optimise uptake. The program is also intended as an information-provision model for other conditions with poorly met needs. 
Table 2

Agencies producing information for people with young onset dementia and carers.

\begin{tabular}{|c|c|c|c|c|c|c|c|}
\hline Source Category & England & France & Germany & Netherlands & Portugal & Sweden & All \\
\hline $\begin{array}{l}1 \text { Government/ } \\
\text { other public } \\
\text { sector }\end{array}$ & $\begin{array}{l}\text { - National Health Service pa- } \\
\text { tient information website }\end{array}$ & 0 & & $\begin{array}{l}\text { - Netherlands Christian Radio } \\
\text { Association website-video N2 } \\
\text { - Limberg Public Radio and TV } \\
\text { Broadcaster website-video }{ }^{\mathrm{N} 3}\end{array}$ & 0 & $\begin{array}{l}\text { - National Board of Health and } \\
\text { Welfare website, book S1 } \\
\text { - Swedish Institute of Assistive } \\
\text { Technology website, maga- } \\
\text { zine S2 }\end{array}$ & 5 \\
\hline $\begin{array}{l}2 \text { Provider or } \\
\text { professional } \\
\text { organisations }\end{array}$ & 0 & 0 & & $\begin{array}{l}\text { - Alzheimer Centre Limberg } \\
\text { (tertiary dementia treat- } \\
\text { ment centre, with Maastrict } \\
\text { University School of Mental } \\
\text { Health \& Neuroscience) } \\
\text { website: online materials, } \\
\text { video, book }{ }^{\mathrm{N} 1}\end{array}$ & 0 & 0 & 1 \\
\hline $\begin{array}{l}3 \text { Third sector } \\
\text { (voluntary, } \\
\text { charity) }\end{array}$ & $\begin{array}{l}\text { - Social Care Institute of Ex- } \\
\text { cellence web video }{ }^{\mathrm{E} 3} \\
\text { - Alzheimer's Society website } \\
\text { factsheet }{ }^{\mathrm{E} 4} \\
\text { - Young Dementia UK website: } \\
6 \text { sections, includes video }{ }^{\mathrm{E} 1}\end{array}$ & $\begin{array}{l}\text { - National YOD reference } \\
\text { centre website F1 } \\
\text { - France Alzheimer: } 3 \text { website } \\
\text { entries, } 2 \text { with videos }{ }^{\mathrm{F} 2}\end{array}$ & $\begin{array}{l}\text { - Alzheimer's Society of } \\
\text { Munich website }{ }^{\mathrm{G}} \\
\text { - German Alzheimer's Society } \\
\text { website: } 2 \text { items }{ }^{\mathrm{G} 2}\end{array}$ & $\begin{array}{l}\text { Dutch Alzheimer's Society } \\
\text { website: } 3 \text { items includes } \\
\text { video }^{\mathrm{N4}}\end{array}$ & $\begin{array}{l}\text { - Alzheimers Portugal website } \\
\text { P1 } \\
\text { - ADVITA, non-profit organi- } \\
\text { sation produces training } \\
\text { materials for formal and } \\
\text { informal carers website } \\
\text { video }^{\mathrm{P} 2} \text {. }\end{array}$ & 0 & 10 \\
\hline $\begin{array}{l}4 \text { Pharmaceutical } \\
\text { companies }\end{array}$ & 0 & 0 & 0 & 0 & 0 & 0 & 0 \\
\hline $\begin{array}{l}5 \text { Commercial, } \\
\text { publishing, } \\
\text { online }\end{array}$ & 0 & $\begin{array}{l}\text { Doctissimo online for profit } \\
\text { health information service, } 2 \\
\text { articles }{ }^{\mathrm{F} 3}\end{array}$ & 0 & 0 & 0 & 0 & 1 \\
\hline $\begin{array}{l}6 \text { Commercial, } \\
\text { publishing, books }\end{array}$ & $\begin{array}{l}\text { - Eckersley, Coping with early } \\
\text { onset dementia }{ }^{\mathrm{E} 5} \\
\text { - Guttman, Early onset } \\
\text { dementia }^{\mathrm{E} 6}\end{array}$ & 0 & 0 & $\begin{array}{l}\text { - Janssens et al., Finding your } \\
\text { way in YOD } \\
\text { - Janssens \& De Vugt, YOD }{ }^{\mathrm{N} 6}\end{array}$ & 0 & 0 & 4 \\
\hline Total & 6 & 3 & 2 & 6 & 2 & 2 & 21 \\
\hline
\end{tabular}


Table 3

Details of information for people with young onset dementia and carers, by agency.

\begin{tabular}{|c|c|c|c|c|c|c|c|c|c|c|c|c|c|c|c|}
\hline \multirow{2}{*}{$\underset{⿱ 乛 龰}{5}$} & \multirow[b]{2}{*}{ 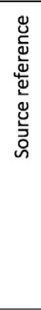 } & \multirow{2}{*}{$\begin{array}{l}\text { Agency/ publisher / } \\
\text { author }\end{array}$} & \multirow{2}{*}{$\begin{array}{l}\text { Source } \\
\text { category }\end{array}$} & \multirow{2}{*}{$\begin{array}{l}\text { Type of } \\
\text { material }\end{array}$} & \multirow{2}{*}{$\begin{array}{l}\text { Size, } \\
\text { pages }\end{array}$} & \multirow[t]{2}{*}{ Price } & \multirow[t]{2}{*}{ Content - description } & \multicolumn{8}{|c|}{ Topic areas } \\
\hline & & & & & & & & 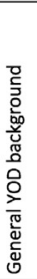 & 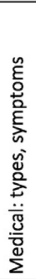 & 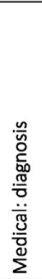 & 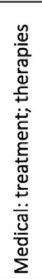 & 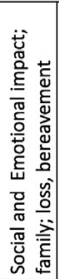 & 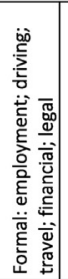 & 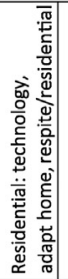 & 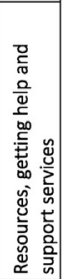 \\
\hline \multirow{6}{*}{ 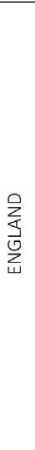 } & E1 & Young Dementia UK & $\begin{array}{l}\text { Charity/ } \\
\text { Voluntary }\end{array}$ & $\begin{array}{l}\text { Text (with } \\
\text { audio; } \\
\text { video (10 } \\
\text { mins) }\end{array}$ & $\begin{array}{l}\text { Whole } \\
\text { site }\end{array}$ & Free & $\begin{array}{l}\text { Dedicated website for YOD with key aspects } \\
\text { covered in well-organised sections and sub } \\
\text { sections. Comprehensive cover of all main issues. }\end{array}$ & & & & & & & & \\
\hline & E2 & $\begin{array}{l}\text { NHS Choices (patient } \\
\text { information website) }\end{array}$ & $\begin{array}{l}\text { National } \\
\text { Government }\end{array}$ & $\begin{array}{l}\text { Video ( } 4 \\
\text { mins); text }\end{array}$ & 1 & Free & $\begin{array}{l}\text { What YOD is, value of early diagnosis, planning for } \\
\text { future, couple explain how they adapted to YOD. }\end{array}$ & & & & & & & & \\
\hline & E3 & $\begin{array}{l}\text { Social Care Institute of } \\
\text { Excellence }\end{array}$ & $\begin{array}{l}\text { Charity/ } \\
\text { Voluntary }\end{array}$ & $\begin{array}{l}\text { Video (10 } \\
\text { mins); text }\end{array}$ & 1 & Free & $\begin{array}{l}\text { Website for professional carers but states video } \\
\text { also for patients / family carers. Two people with } \\
\text { YOD explain experiences. }\end{array}$ & & & & & & & & \\
\hline & E4 & Alzheimer's Society & $\begin{array}{l}\text { Charity/ } \\
\text { Voluntary }\end{array}$ & $\begin{array}{l}\text { Factsheet, } \\
\text { as PDF }\end{array}$ & 19 & Free & $\begin{array}{l}\text { Website with section for YOD: general problems of } \\
\text { YOD, where to get help, links to factsheets for } \\
\text { dementia in general e.g. driving, working. }\end{array}$ & & & & & & & & \\
\hline & E5 & $\begin{array}{l}\text { Eckersley J, Sheldon } \\
\text { Press, } 2011\end{array}$ & $\begin{array}{l}\text { Book } \\
\text { publisher }\end{array}$ & $\begin{array}{l}\text { Book: } \\
\text { hard and } \\
\text { e-copy }\end{array}$ & 115 & $\begin{array}{l}f 7.35 \\
f 6.86\end{array}$ & $\begin{array}{l}\text { 'Coping with early onset dementia'; covers all } \\
\text { aspects. }\end{array}$ & & & & & & & & \\
\hline & E6 & $\begin{array}{l}\text { Guttman E, } \\
\text { LCPublifish, } 2014\end{array}$ & $\begin{array}{l}\text { Book } \\
\text { publisher }\end{array}$ & $\begin{array}{l}\text { Electronic } \\
\text { book }\end{array}$ & 32 & f1.99 & $\begin{array}{l}\text { 'Early onset dementia', detection, symptoms, } \\
\text { treatment and caregiving. }\end{array}$ & & & & & & & & \\
\hline \multirow[b]{3}{*}{ 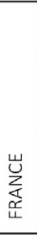 } & F1 & $\begin{array}{l}\text { National YOD } \\
\text { reference centre }\end{array}$ & $\begin{array}{l}\text { Charity/ } \\
\text { Voluntary }\end{array}$ & Text & $\begin{array}{l}\text { Whole } \\
\text { site }\end{array}$ & Free & $\begin{array}{l}\text { Dedicated website: details about centre, diagnosis, } \\
\text { disease types, treatment, rights, other resources. }\end{array}$ & & & & & & & & \\
\hline & F2 & France Alzheimer's & $\begin{array}{l}\text { Charity/ } \\
\text { Voluntary }\end{array}$ & Text & 44 & Free & $\begin{array}{l}\text { Website includes chapter on YOD, amongst general } \\
\text { dementia resources with links, and carer's guide in } \\
\text { form of a massive online open course (MOOC). }\end{array}$ & & & & & & & & \\
\hline & $\mathrm{F3}$ & $\begin{array}{l}\text { Doctissimo- } \\
\text { monitored health } \\
\text { information website }\end{array}$ & $\begin{array}{l}\text { Online } \\
\text { commercial }\end{array}$ & $\begin{array}{l}\text { Text }-2 \\
\text { articles }\end{array}$ & $2+3$ & Free & $\begin{array}{l}\text { Early signs and symptoms of YOD, diagnosis, } \\
\text { treatment, help available. } \\
\text { Report of France Alzheimer's study on YOD needs } \\
\text { and services. }\end{array}$ & & & & & & & & \\
\hline \multirow{2}{*}{ 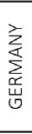 } & G1 & $\begin{array}{l}\text { Alzheimer's Society of } \\
\text { Munich website }\end{array}$ & $\begin{array}{l}\text { Charity/ } \\
\text { Voluntary }\end{array}$ & $\begin{array}{l}\text { Text - } \\
\text { article }\end{array}$ & 16 & Free & $\begin{array}{l}\text { Dementia in middle of life, different forms of } \\
\text { support; seminar 'despite dementia' on coping. }\end{array}$ & & & & & & & & \\
\hline & G2 & $\begin{array}{l}\text { German Alzheimer's } \\
\text { Society website }\end{array}$ & $\begin{array}{l}\text { Charity/ } \\
\text { Voluntary }\end{array}$ & $\begin{array}{l}\text { Text }-2 \\
\text { items }\end{array}$ & 2 & Free & $\begin{array}{l}\text { Project summary: 'Dementia in the middle of life, } \\
\text { what does it mean?' with aim to improve services. } \\
\text { Information on practical aspects. }\end{array}$ & & & & & & & & \\
\hline \multirow{6}{*}{ 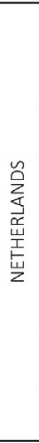 } & N1 & $\begin{array}{l}\text { Alzheimer's Centre } \\
\text { Limberg website }\end{array}$ & $\begin{array}{l}\text { Provider } \\
\text { organisation }\end{array}$ & $\begin{array}{l}\text { Text, } \\
\text { video ( } 64 \\
\text { mins) and } \\
\text { book }\end{array}$ & $\begin{array}{l}\text { Whole } \\
\text { site: } 84 \text {; } \\
\text { Book: } 63\end{array}$ & $\begin{array}{l}\text { Free; } \\
\text { Book, } \\
5 \\
\text { euros }\end{array}$ & $\begin{array}{l}\text { Section dedicated to YOD: all major issues covered } \\
\text { Documentary: young person with dementia } \\
\text { entering nursing home. } \\
\text { Book: characteristics, treatment, care, impact. }\end{array}$ & & & & & & & & \\
\hline & N2 & $\begin{array}{l}\text { Netherlands Christian } \\
\text { Radio Assoc. website }\end{array}$ & $\begin{array}{l}\text { Public } \\
\text { agency }\end{array}$ & $\begin{array}{l}\text { Video }(23 \\
\text { mins) }\end{array}$ & - & Free & $\begin{array}{l}\text { Documentary about living with YO Alzheimer's and } \\
\text { struggles of family with euthanasia. }\end{array}$ & & & & & & & & \\
\hline & N3 & $\begin{array}{l}\text { Limburg Public Radio } \\
\& \text { TV Broadcaster } \\
\text { website }\end{array}$ & $\begin{array}{l}\text { Public } \\
\text { agency }\end{array}$ & $\begin{array}{l}\text { Video (50 } \\
\text { mins) }\end{array}$ & - & Free & $\begin{array}{l}\text { Couple followed during } 5 \text { years after husband } \\
\text { received dementia diagnosis at young age. }\end{array}$ & & & & & & & & \\
\hline & N4 & $\begin{array}{l}\text { Dutch Alzheimer's } \\
\text { Society website }\end{array}$ & $\begin{array}{l}\text { Charity/ } \\
\text { Voluntary }\end{array}$ & $\begin{array}{l}\text { Text, } \\
\text { video ( } 45 \\
\text { mins) and } \\
\text { booklet }\end{array}$ & 28 & $\begin{array}{l}\text { Free; } \\
\text { Video, } \\
15 \\
\text { Euros }\end{array}$ & $\begin{array}{l}\text { Subsection of website covers important aspects of } \\
\text { YOD; list of specialist YOD providers. Video on } \\
\text { dementia includes clips on YOD. }\end{array}$ & & & & & & & & \\
\hline & N5 & $\begin{array}{l}\text { Janssens et al, Lannoo } \\
\text { Campus, } 2007\end{array}$ & $\begin{array}{l}\text { Book } \\
\text { publisher }\end{array}$ & Book & 256 & $\begin{array}{l}19.95 \\
\text { Euros }\end{array}$ & $\begin{array}{l}\text { 'Finding your way in YOD'. Comprehensive practical } \\
\text { guide, patients, families, professionals. }\end{array}$ & & & & & & & & \\
\hline & N6 & $\begin{array}{l}\text { Janssens \& De Vugt, } \\
\text { Lannoo Campus, } 2014\end{array}$ & $\begin{array}{l}\text { Book } \\
\text { publisher }\end{array}$ & Book & 190 & $\begin{array}{l}24.95 \\
\text { Euros }\end{array}$ & $\begin{array}{l}\text { Latest scientific evidence, epidemiology, trajectory, } \\
\text { impact, personal experiences. }\end{array}$ & & & & & & & & \\
\hline \multirow{2}{*}{ 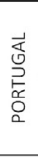 } & P1 & $\begin{array}{l}\text { Alzheimer's Portugal } \\
\text { website }\end{array}$ & $\begin{array}{l}\text { Charity/ } \\
\text { Voluntary }\end{array}$ & Text & $\begin{array}{l}\text { Whole } \\
\text { site }\end{array}$ & Free & $\begin{array}{l}\text { Information exclusively on YO Alzheimer's, } \\
\text { definition, causes, diagnosis, symptoms, care, } \\
\text { services, driving. }\end{array}$ & & & & & & & & \\
\hline & P2 & $\begin{array}{l}\text { ADVITA, organisation } \\
\text { provides training } \\
\text { videos }\end{array}$ & $\begin{array}{l}\text { Charity/ } \\
\text { Voluntary }\end{array}$ & $\begin{array}{l}1 \text { video } \\
\text { (16 mins) }\end{array}$ & & Free & $\begin{array}{l}\text { Information about dealing with behavioural } \\
\text { changes in dementia, including in YOD. }\end{array}$ & & & & & & & & \\
\hline \multirow{2}{*}{ 喋 } & S1 & $\begin{array}{l}\text { National Board of } \\
\text { Health and Welfare } \\
\text { website }\end{array}$ & $\begin{array}{l}\text { National } \\
\text { Government }\end{array}$ & $\begin{array}{l}\text { Text - } \\
\text { Booklet to } \\
\text { download }\end{array}$ & 23 & Free & $\begin{array}{l}\text { Dementia support for patients and carers about } \\
\text { NBHW guidelines for care. YOD specifically } \\
\text { mentioned in some parts. }\end{array}$ & & & & & & & & \\
\hline & S2 & $\begin{array}{l}\text { Swedish Agency for } \\
\text { Participation website }\end{array}$ & $\begin{array}{l}\text { National } \\
\text { Government }\end{array}$ & $\begin{array}{l}\text { Text - } \\
\text { Magazine }\end{array}$ & 26 & & $\begin{array}{l}\text { For younger people with dementia, technology } \\
\text { available making it possible to stay at home longer. }\end{array}$ & & & & & & & & \\
\hline
\end{tabular}

\section{Acknowledgements}

RHAPSODY is an EU Joint Programme - Neurodegenerative Disease Research (JPND) project. The project is supported through the following funding organisations under the aegis of JPND (www. jpnd.eu). France: National Research Agency; Germany: Ministry of Education and Research; The Netherlands: The Netherlands Organisation for Health Research and Development; Portugal:
Foundation for Science and Technology; Sweden: The Swedish Research Council; United Kingdom: Economic and Social Research Council.

\section{Appendix A.}

Source references for Table 3: Details of information for people with young onset dementia and carers, by agency 


\section{England}

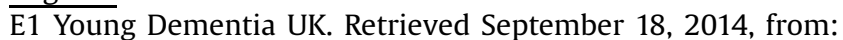
https://www.youngdementiauk.org/

E2 NHS Choices (patient information website). Retrieved October 22, 2014 from: http://www.nhs.uk/video/pages/earlyonsetdementia.aspx; http://www.nhs.uk/CarersDirect/carerslives/ realstories/Pages/Marysstory.aspx

E3 Social Care Institute of Excellence (SCIE). Retrieved October 22, 2014 from: http://www.scie.org.uk/socialcaretv/video-player. asp?guid=61aa9350-6c43-4098-bb5d-1c0ee733f3c7

E4 Alzheimer's Society UK. Retrieved September 15, 2014, from: http://www.alzheimers.org.uk/site/scripts/documents_info.php? documentID $=164$

E5 Eckersley, J. (2011). Coping with early onset dementia. Sheldon Press. Retrieved June 19, 2015, from: Amazon.co.uk

E6 Guttman, E. (2014). Early onset dementia: Caring for a loved one with EOD. LCPublifish. Retrieved June 19, 2015, from: Amazon. co.uk.

\section{France}

F1 Centre National de Référence des Malades Alzheimer Jeunes. (entire website): http://www.centre-alzheimer-jeunes.fr/index. php (Accessed 30th September 2016)

F2 France Alzheimer (2007). Vivre avec un malade jeune: Accompagner une personne atteinte d'une maladie d'Alzheimer ou d'une maladie apparentée avant 65 ans. http://issuu.com/francealzheimer/docs/brochure_malade_jeune/1?e=17038647/

31539882 (Accessed 30th September 2016)

F3 Doctissimo: Maladie d'Alzheimer, quelles sont ses particularités chez le sujet jeune? (webpage) http://www.doctissimo.fr/ html/dossiers/alzheimer/15030-alzheimer-precoce.htm (Accessed 30th September 2016)

Alzheimer précoce: des besoins spécifiques. (webpage) http:// www.doctissimo.fr/html/dossiers/alzheimer/15489-alzheimeravant-60-ans.htm (Accessed 30th September 2016)

\section{Germany}

G1 Alzheimer Gesellschaft München (n.d.). Demenz mitten im Leben. http://www.agm-online.de/projekt-demil.html (Accessed July 23rd 2016)

G2 Deutsche Alzheimer Gesellschaft (2008). Demenz mitten im Leben - Was bedeutet das? https://www.deutsche-alzheimer.de/ unser-service/archiv-alzheimer-info/demenz-mitten-im-leben.

html (Accessed July 23rd 2016)

Netherlands

N1 Alzheimer Centre Limburg http://www.jongdementie.info/ (Accessed September 23, 2016)

N2 http://www.npo.nl/ncrv-dokument-voor-ik-het-vergeet/ 07-12-2009/NCRV_1352364 (Accessed September 23, 2016)

N3 Website for people with YOD and carers supported by the Alzheimer Centre Limburg, Memo Expertisecentrum Dementie Vlaanderen, The Alzheimer Liga Vlaanderen and Expertisecentrum Dementie Vlaanderen. www.jongdementie.info (Accessed September 23rd, 2016)

Video: http://www.l1.nl/nieuws/documentaire-mist (Accessed September 23, 2016)

N4 https://www.alzheimer-nederland.nl/dementie/op-jongeleeftijd (Accessed September 23, 2016)

N5 Janssens, A., Lootens, A., Verraest, E. \& Mattheussen, I. (2007) Wegwijs in dementie op jonge leeftijd: een praktische gids voor personen met jongdementie, familie en hulpverleners. www.bol. com (Accessed September 23, 2016)

N6 Janssens, A. \& De Vugt, M. (2014) Dementie op jonge leeftijd. www.bol.com (Accessed September 23, 2016)

Portugal

P1 Alzheimer Portugal. (2015). Demência Precoce. http:// alzheimerportugal.org/pt/demencia-precoce (Accessed 30th September 2016)
P2 Associação para o desenvolvimento de novas iniciativas para a vida. (2015). http://advita.pt/filmes-cuidar (Accessed 30th September 2016)

Sweden

S1 Demenssjukdom - stöd för dig som har en demenssjukdom och för dina närstående. Stockholm: Socialstyrelsen. http://www. socialstyrelsen.se/Lists/Artikelkatalog/Attachments/18649/20123-23.pdf (Accessed 30th September 2016)

S2 Ett magasin om teknik och demens: hjälpmedel finns för personer med demens. Vällingby: Hjälpmedelsinstitutet. http:// www.mfd.se/globalassets/dokument/publikationer/2007/07361ett-magasin-om-teknik-och-demens.pdf (Accessed 30th September 2016)

\section{References}

[1] World Health Organisation and Alzheimer's Disease International. Dementia: a public health priority. 2012

[2] Organisation of Economic Cooperation and Development, Addressing Dementia: The OECD Response. OECD Health Policy Studies. 2015.

[3] Alzheimer's Europe National Dementia Plans. http://www.alzheimer-europe org/Policy-in-Practice2/National-Dementia-Plans. (Accessed 5th January 2016).

[4] R.J. Harvey, M. Skelton-Robinson, M.N. Rossor, The prevalence and causes of dementia in people under the age of 65 years, J. Neurol. Neurosurg. Psychiatry 74 (2003) 126-129.

[5] L. Mercy, J.R. Hodges, K. Dawson, R.A. Barker, C. Brayne, Incidence of earlyonset dementias in Cambridgeshire, United Kingdom, Neurology 71 (2008) 1496-1499.

[6] C. Bakker, M.E. de Vugt, M. Vernooij-Dassen, D, van Vliet, F.R.J. Verhey, R.T.C. Koopmans, Needs in early onset dementia: a qualitative case from the NeedYD Study, Am. J. Alzheimers Dis. Other Demen. 25 (2010) 634-640.

[7] M.F. Mendez, The accurate diagnosis of early-onset dementia, Int. J. Psychiatry Med. 36 (2006) 401-412.

[8] P.E. Cohn-Hokke, M.W. Elting, Y.A.L. Pijnenburg, J.C. van Swieten, Genetics of dementia: update and guidelines for the clinician, Am. J. Genet. 159B (2012) 628-643.

[9] N.C. Kaiser, R.J. Melrose, C. Liu, D.L. Sultzer, E. Jimenez, M. Su, L. Monserratt, M. F. Mendez, Neuropsychological and neuroimaging markers in early versus late-onset Alzheimer's disease, Am. J. Alzheimers Dis. Other Demen. 27 (2012) $520-529$.

[10] Koedam ELGE, V. Lauffer, A.E. van der Vlies, W.M. van der Flier, P. Scheltens, Y.A L. Pijnenburg, Early-versus late-onset Alzheimer's disease: more than age aloneq, J. Alzheimer's Dis. 19 (2010) 1401-1408.

[11] D.K. Kuruppu, B.R. Matthews, Young-onset dementia, Semin. Neurol. 33 (2013) 365-385.

[12] E. Sampson, J.D. Warren, M.N. Rossor, Young onset dementia, Postgrad. Med. J. 80 (2004) 125-139.

[13] R. Koopmans, Young onset dementia ?what does the name imply?, Int Psychogeriatr. 26 (Special issue 12) (2014) 1931-1933.

[14] J.K. Millenaar, D. van Vliet, C. Bakker, M.J. Vernooij-Dassen, R.T. Koopmans, F.R. Verhey, de Vugt ME.The experiences and needs of children living with a parent with young onset dementia: results from the NeedYD study, Int. Psychogeriatr 26 (2014) 2001-2010.

[15] A. Arai, T. Matsumoto, M. Ikeda, Y. Arai, Do family caregivers perceive more difficulty when they look after patients with early onset dementia compared to those with late onset dementia? Int. J. Geriatr. Psychiatry 22 (2007) 1255-1261.

[16] J. Sansoni, C. Duncan, P. Grootemaat, P. Samsa, J. Capell, Younger Onset Dementia: a Literature Review. Research Online, University of Wollongong, 2014 http://ro.uow.edu.au/cgi/viewcontent.cgi?article=1380\&context=ahsri (Accessed 5th January 2016).

[17] E. Svanberg, A. Spector, J. Stott, The impact of young onset dementia on the family: a literature review, Int. Psychogeriatr. 23 (2014) 356-371.

[18] P.B. Harris, Intimacy, sexuality, and early-stage dementia: the changing marital relationship, Alzheimers Care Today 10 (2009) 63-77.

[19] F. Ducharme, M.J. Kergoat, F. Pasquier, R. Coulombe, The unique experience of spouses in early-onset dementia, Am. J. Alzheimers Dis. Other Demen. 28 (2013) 634-641.

[20] L.O. Nichols, J. Martindale-Adams, W.A. Greene, R. Burns, M.J. Graney, A. Lummus, Dementia caregiver's most pressing concerns, Clin. Gerontol. 32 (2009) 1-14.

[21] S.B. Wackerbarth, M.M.S. Johnson, Essential information and support needs of family caregivers, Patient Educ. Couns. 47 (2002) 95-100.

[22] K.T. Washington, S.E. Meadows, S.G. Elliott, R.J. Koopmans, Information needs of informal caregivers of older adults with chronic health conditions, Patient Educ. Couns. 83 (2011) 37-44.

[23] J.C. Prorok, S. Horgan, D.P. Seitz, Health care experiences of people with dementia and their caregivers: a meta-ethnographic analysis of qualitative studies, CMAJ (2013), doi:http://dx.doi.org/10.1503/cmaj.121795. 
[24] C.J. Farran, D. Loukissa, S. Perraud, O. Paun, Alzheimer's disease caregiving information and skills. Part II: family caregiver issues and concerns, Res. Nurs. Health 27 (1) (2004) 40-51.

[25] Staistica Share of households with internet access in the United Kingdom (UK) and the European Union (EU28) from 2007 to 2015 https://www.statista.com/ statistics/275043/percentage-of-households-with-internet-access-in-the-ukand-eu/ (Accessed 16th November 2016).

[26] Young-onset dementia: Understanding your diagnosis. Alzheimer's Society (2017). https://www.alzheimers.org.uk/info/20033/ publications_and_factsheets/923/young-

onset_dementia_understanding_your_diagnosis. (Accessed 3rd April 2017).

[27] S.D. Lambert, C.G. Loiselle, Health information seeking behaviour, Qual. Health Res. 17 (8) (2007) 1006-1019.

[28] H. Brodaty, A. Green, A. Koschera, Meta-analysis of psychosocial interventions for caregivers of people with dementia, J. Am. Geriatr. Soc. 51 (2003) 657-664.
[29] L.Y. Chien, H. Chu, J.L. Guo, Y.M. Liao, L.I. Chang, C.H. Chen, K.R. Chou, Caregiver support groups in patients with dementia: a meta analysis, Int. J. Geriatr. Psychiatry 26 (2011) 1086-1098.

[30] S. Sörensen, P. Duberstein, D. Gill, M. Pinquart, Dementia care: mental health effects, intervention strategies, and clinical implications, Lancet Neurol. 5 (2006) 961-973.

[31] S. Sorbi, J. Hort, T. Erkinjuntti, T. Fladby, G. Gainotti, H. Gurvit, B. Nacmias, F. Pasquier, B.O. Popescu, I. Rektorova, D. Religa, R. Rusina, M. Rossor, R. Schmidt, E. Stefanova, J.D. Warren, P. Scheltens, EFNS scientist panel on dementia and cognitive neurology: EFNS-ENS guidelines on the diagnosis and management of disorders associated with dementia, Eur. J. Neurol. 19 (2012) 1159-1179.

[32] A. Kurz, on behalf of the RHAPSODY Study Group, RHAPSODY-a european initiative to support people with young onset dementia and their informal carers, Int. Psychogeriatr. (2016), doi:http://dx.doi.org/10.1017/ S1041610216001186. 